\title{
Synergistic effect of phosphate solubilizing rhizobacteria and arbuscular mycorrhiza on growth and yield of wheat plants
}

\author{
Minaxi $^{1}$, J. Saxena ${ }^{2 *}$, S. Chandra ${ }^{3}$, and L. Nain ${ }^{4}$ \\ ${ }^{I}$ Department of Bioscience and Biotechnology, Banasthali University, Banasthali-304022, Rajasthan, India. ${ }^{2}$ Biochemical \\ Engineering Department, B.T. Kumaon Institute of Technology, Dwarahat, India. ${ }^{3}$ Departament of Statistics Banasthali University \\ Rajasthan, India. ${ }^{4}$ Division of Microbiology, Indian Agricultural Research Institute, New Delhi-110012 India ${ }^{*}$ Corresponding \\ author: saxenajyoti30@gmail.com
}

\begin{abstract}
The present communication is an attempt to explore the synergistic effect of two indigenous phosphate solubilizing bacteria (PSB) (Pseudomonas fluorescens BAM-4 and Burkholderia cepacia BAM-12) and arbuscular mycorrhizal (AM) fungus, Glomus etunicatum on growth, yield and nutrient uptake of wheat plants grown in nutrient deficient soils in pots amended with tricalcium phosphate (TCP). A significant increase in growth, yield and nutrient uptake of wheat plants was noticed and both strains of PSB interacted positively with AM fungus towards all growth parameters studied. A remarkable enhancement of seed yield was recorded notably by $92.8 \%$ and an increase in percent root colonization of AM and PSB population in soil was also recorded with time.
\end{abstract}

Keywords: Wheat, Pseudomonas fluorescens, Burkholderia cepacia, arbuscular mycorrhiza (AM), TCP

\section{Introduction}

Large amounts of chemical fertilizers are generally used to improve growth and yield of crops. However, increasing costs of these fertilizers and environmental concerns related to their use have led to the development of alternative strategies. The use of beneficial soil microorganisms could reduce the amount of fertilizer input by increasing the efficiency of nutrient availability and other plant growth promoting activities. Biofertilizers hold a promise to balance many drawbacks of the conventional chemical based technology and could recuperate healthy farming practices and organic farming.
Arbuscular mycorrhizal fungi (AM) are known to occur widely under various environmental conditions and are found associated with roots of most of the food crops (Chen et al., 2005; Souchie et al., 2006). The AM fungi form a filamentous network in soil and plant roots which promotes bi-directional nutrient movement. Nutrients taken up by the mycorrhizal fungi can lead to improved plant growth and reproduction in infertile soils. As a result, mycorrhizal plants are often more competitive and are able to tolerate environmental stresses compared to non-mycorrhizal plants. The application of AM fungi led to noteworthy 
enhancements on plant growth, vigour, nutrient and water uptake, disease resistance and drought tolerance (Raj et al., 1981; Jeffries et al., 2003; Sanchez-Blanco et al., 2004; Göhre and Paszkowski, 2006; Wu and Xia, 2006).

Plant growth promoting rhizobacteria (PGPR), especially phosphate solubilizing bacteria (PSB), which reside in the plant rhizosphere, increase the availability of $\mathrm{P}$ for the plants by solubilization of bound $\mathrm{P}$ in soil (Illmer et al., 1995; Rodriguez and Fraga, 1999; Igual et al., 2001). Due to limited diffusion and formation of a Pi-depletion zone surrounding the root system, the phosphate made available by PSB from sparingly soluble inorganic $\mathrm{P}(\mathrm{Pi})$ sources may not reach the root surface, therefore it was proposed that if the solubilized phosphate was taken up first by AM mycelium, this synergistic microbial interaction should improve P supply to the plant. In particular, AM inoculation improves the establishment of both inoculated and indigenous phosphate-solubilizing rhizobacteria acting as helping bacteria (Barea et al., 2002). It was found that plants inoculated with AM fungi either alone or in combination with PSB, increased the $\mathrm{P}$ uptake remarkably in many cash crops such as wheat and maize (Evans and Mille, 1990; Raja et al., 2002).

India is the second largest producer of wheat in the world. It is predicted in relation to the rate and nature of economic growth, population expansion and income elasticity that there would be a demand of 4 to $5 \%$ annual rate increase in wheat production. In order to increase the production, the technologies utilizing indigenous microbes need to be further explored and developed.

Two bacterial strains, Pseudomonas fluorescens BAM-4 and Burkholderia cepacia BAM-12 were isolated by the authors from semi arid agriculture soil of Rajasthan, India and showed great potential to solubilize phosphorus in vitro and disease suppression and crop improvement in vivo in mung beans (Vigna radiata) (Anamika et al., 2007; Minaxi and Saxena,
2010). These strains have enormous possibilities to be used in field applications as bioinoculants for various crops. Glomus etunicatum, a mycorrhizal fungus, commonly found associated with root of wheat plants can also be used as co-inoculant to enhance their capacity for crop improvement in arid and semi arid regions. The current experiment was designed to assess the effects of Pseudomonas fluorescens BAM4 and Burkholderia cepacia BAM-12 along with Glomus etunicatum in presence and absence of hardly soluble tricalcium phosphate (TCP) on biomass, mycorrhizal colonization, yield and nutrient uptake by plants. A successful application could lead to the development of a biofertilizer based on the strains tested in this study.

\section{Materials and Methods}

\subsection{Microbial cultures and seeds}

The bacterial strains $P$. fluorescens BAM-4 and $B$. cepacia BAM-12 were isolated from rhizosphere soil of agriculture plants grown in semi arid region of Banasthali, Rajasthan (India) and screened for phosphate solubilization. These 2 strains solubilized 170 and $180 \mathrm{ppm} \mathrm{P}$ in vitro after $24 \mathrm{~h}$ of incubation. The cultures were identified by IMTECH, Chandigarh, India. The accession numbers are MTCC 7098 and MTCC 7100, respectively. The AM inoculum consisted of chopped root segments from a 10-week-old pot culture of Glomus etunicatum grown on wheat in sterile sandy soil.

Seeds of wheat (Triticum aestivum cv. Raj 3765) were obtained from the Krishi Vigyan Kendra (KVK), Banasthali University, Rajasthan and surface sterilized by immersing in $0.1 \%$ of $\mathrm{HgCl}_{2}$ prepared in sterile distilled water (d.w.) for $3 \mathrm{~min}$. Seeds were then rinsed with sterile d.w. 3 times, blotted on a sterile filter paper, dried and kept for future use. All steps were carried out in a laminar air flow cabinet (LAF). 


\subsection{Preparation of inoculum}

Single colonies of each bacterium were inoculated in $50 \mathrm{ml}$ of LB medium and incubated at $30 \pm 2^{\circ} \mathrm{C}$ in an orbital incubator shaker for 2 days at $130 \mathrm{rpm}$. Jaggery slurry was prepared in d.w, cooled and mixed with bacterial cultures to enable proper seed coating. Wheat seeds were pelleted with bacterial cultures at a concentration of $10^{8}$ cells $\mathrm{ml}^{-1}$. Seeds coated with uninoculated medium and jaggery mixture served as controls. Seeds were kept for drying on a clean surface sterilized plastic sheet in LAF.

\subsection{Soil analysis}

The soil was analyzed for physico-chemical characteristics before filling the pots. The soil used in this study was clay collected from $0-25 \mathrm{~cm}$ depth with $0.41 \%$ organic matter (unpublished data of KVK, Banasthali). It was thoroughly mixed and sieved through a $2 \mathrm{~mm}$ sieve, sterilized in an oven for 2 hours at $140^{\circ} \mathrm{C}$ and then filled in ethanol disinfected plastic pots for various experiments. The method of Allen (1989) was followed to determine the soil $\mathrm{pH}$. The available $\mathrm{P}$ was determined using the method of Olsen et al. (1954). Total phosphorus concentration of soil samples was determined following the method of Olsen and Sommers (1982).

\subsection{Experimental design and seed sowing}

The inoculation treatments were set in a randomized block design. The treatments were as follows: T1Uninoculated control (UC) (seed coated with media), T2- UC+SSP (0.2 $\mathrm{g} \mathrm{kg}^{-1}$ soil), T3- UC+biofertilizer (seed pelleting), T4- UC $+1 \mathrm{~g}$ G. etunicatum $\mathrm{kg}^{-1}$ soil, T5-UC $+1 \mathrm{~g}$ G. etunicatum $\mathrm{kg}^{-1}$ soil + TCP $\left(0.2 \mathrm{~g} \mathrm{~kg}^{-1}\right.$ soil), T6- seed coated with BAM-4, T7- seed coated with BAM-4+TCP, T8- seed coated with BAM-12, T9- seed coated with BAM-12+TCP, T10- seed coated with BAM-4+BAM-12, T11- seed coated with BAM4+BAM-12+TCP, T12- BAM-4+1 g G. etunicatum, T13-BAM-4+1 g G. etunicatum +TCP, T14-BAM-12+ $1 \mathrm{~g} \mathrm{G}$. etunicatum, T15- BAM-12+ $1 \mathrm{~g}$ G. etunicatum
+ TCP, T16- BAM-4+BAM-12+1g G. etunicatum and T17- BAM-4+BAM-12+1g G. etunicatum +TCP. The Biofertilizer 'Biogold', commonly marketed and used in semi arid regions, was obtained from Mahesh Pesticides and Fertilizers Ltd., Newai, Rajasthan, India which contained phosphate solubilizing bacteria. Single super phosphate (SSP) obtained from KVK, Banasthali University, Rajasthan was used as chemical fertilizer.

Ten air-dried seeds of wheat were immediately sown at $2 \mathrm{~cm}$ depth in $1 \mathrm{~kg}$ plastic pots (length, $12.5 \mathrm{~cm}$; upper diameter, $12.0 \mathrm{~cm}$; lower diameter, $8.5 \mathrm{~cm}$ ) filled with semi arid soil and watered. Percent seed germination was calculated 5 days after sowing and then seedlings were thinned down to 6 per pot. The experiment was set up in a wire house from $12^{\text {th }}$ Dec 2007 to 1 st April 2008 and the experiment was repeated from Dec 2008 to April 2009. Plants were watered daily to maintain moisture at field capacity. The plants from 2 pots were harvested 45 and 110 days after sowing (DAS) and 3 plants from each pot were used to determine the different parameters.

\subsection{Plant growth parameters}

The germinated seeds were counted on $5^{\text {th }}$ day of sowing and the germination rate was calculated. The dry weight of shoots and roots was measured 45 and 110 DAS. The samples were dried in an oven for 48 hours at $60^{\circ} \mathrm{C}$. Fresh leaves were collected and immediately processed for leaf area measurement. An 'A4' size paper was taken and its weight and area were measured. The leaf was then outlined carefully. The paper within the outlined area was cut and weighed. The leaf area in $\mathrm{cm}^{2}$ was calculated according to the following formula:

$$
\begin{aligned}
& \text { Leaf area }=\frac{\mathrm{a} \times \mathrm{y}}{\mathrm{x}} \\
& \mathrm{a}=\text { area of the A4 paper in } \mathrm{cm}^{2} \\
& \mathrm{y}=\text { weight of the cut paper in } \mathrm{g} \\
& \mathrm{x}=\text { weight of the A4 paper in } \mathrm{g}
\end{aligned}
$$


Four observations were made for each experimental set. The enumeration of PSB was determined 45 and 110 DAS from the rhizosphere soil by the dilution plate technique on Pikovskaya agar medium. Each plate was replicated 3 times, and incubated for 5 days at $28 \pm$ $2^{\circ} \mathrm{C}$. Colonies showing a clear halo around the growth indicating P solubilization were counted. To determine the mycorrhizal colonization of roots, the method of Philips and Hayman (1970) was used. The roots were observed under microscope and the percentage of root colonization was determined by dividing the number of colonized roots by the total number of examined roots.

For determination of phosphorus and nitrogen contents in shoots the oven-dried (at $60^{\circ} \mathrm{C}$ for $48 \mathrm{~h}$ ) shoot samples were processed. Total phosphorus was estimated (Jackson, 1965) and the amount of phosphorus in the samples was calculated using a standard curve. Micro-Kjeldahl method was used for measuring the total nitrogen content of samples (AOAC, 1965) in a Kjeltec Auto analyzer 1030.

Yield parameters were spike length, spike weight, seeds per spike, seeds per plant and weight of 100 grains measured at the time of harvest.

\subsection{Statistical analysis}

Results are expressed as the mean of twelve independent replicates. Analysis of variance (ANOVA) followed by LSD post hoc multiple comparison tests were done using SPSS (version 16.0). The values at $p<0.05$ were considered as statistically significant.

\section{Results}

The soil used for pot experiments had the following characteristics: $\mathrm{pH} 7.4$; total $\mathrm{P} 44.4 \mu \mathrm{g} \mathrm{g}^{-1}$ and available $\mathrm{P} 1.6 \mu \mathrm{g} \mathrm{g}^{-1}$ soil. The organisms used in the experiment were from two different taxonomic groups but complimented each other very well when inoculated together and resulted in better growth and yield of wheat plants. The positive effects of coinoculation of AM fungus and PSB with respect to different parameters are summarized in Tables 1-3 and Figures 1-4.

\subsection{Seed germination}

Wheat seeds coated with rhizobacteria, singly or in combination, with AM revealed a significant increase in percent seed germination at $p<0.05$ in comparison to uninoculated control which had lowest rate of germination i.e. $75.5 \%$ (Figure 1). Dual rhizobacterial combination, BAM-4+BAM-12 with TCP showed maximum increase $(31.8 \%)$ in seed germination amongst all treatments. These values are more than the chemical fertilizer, SSP (84.84\%) and almost at par to commercial biofertilizer, biogold (96.75\%). The percent germination was 85.85 when inoculated with AM fungus only but in rest of the treatments it ranged from $96-98 \%$.

\subsection{Leaf area}

The effect of bacterial inoculation along with AM on leaf area of wheat plants in pot trials is shown in Figure 2. The leaf area of all seed treated plants was found to be significantly $(p<0.05)$ higher than the control. Single rhizobacterial inoculation treatments were found to have almost similar leaf area as SSP and commercial biofertilizer treatments, but when inoculated along with AM showed better results. In combination treatments, BAM-12+BAM-4+AM+TCP increased leaf area significantly $(p<0.05)$ i.e. 64 and $70.2 \%$ over UC at 45 and $110 \mathrm{DAS}$, respectively.

\subsection{Dry weight of shoot}

Table 1 and Figure 5 clearly show that a statistically significant $(p<0.05)$ gain in dry weight of shoots was made by wheat plants when seeds were inoculated with AM and rhizobacterial strains singly or in combination.

The percent increase in dry weight was in the range of 30.5-53.2 in case of AM inoculation with and without TCP over control; BAM-12 and BAM-4 also showed rather less percent increase $(51.9 \%$ and $259.8 \%$ for 
BAM-12 and $62.1 \%$ and $159.6 \%$ increase for BAM4) at 45 and 110 days, respectively as compared to control. The highest increase in shoot dry weight was found in plants treated with both bacteria and AM with TCP.
Forty-five DAS the dry weight was $588.7 \%$ above the untreated control and 110 DAS was increased to $633.1 \%$. In general addition of TCP helped plants to gain more shoot weight.

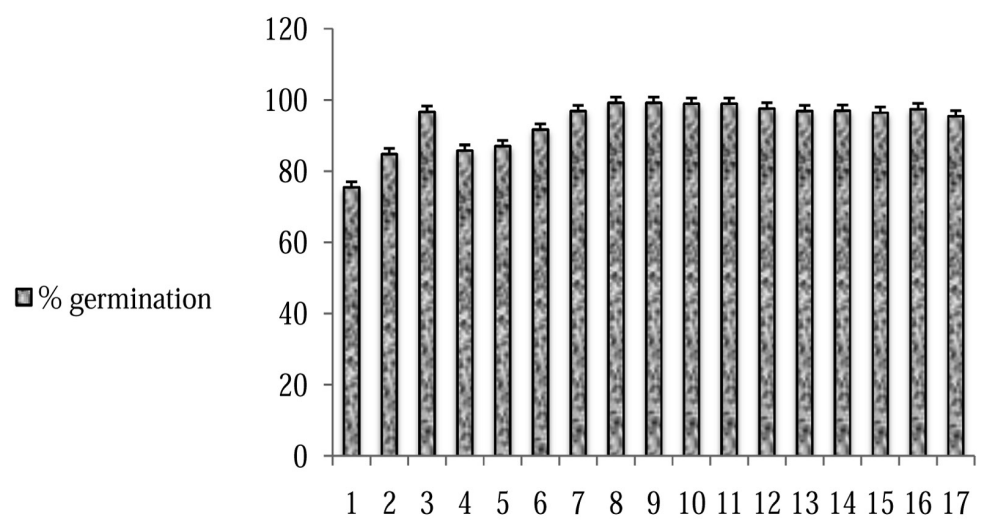

Figure 1. Germination rates (Treatments on $\mathrm{x}$-axis $1=\mathrm{Un}$-inoculated control $(\mathrm{UC}), 2=\mathrm{UC}+\mathrm{SSP}, 3=\mathrm{UC}+\mathrm{Bio}$ fertilizer, $4=\mathrm{UC}+\mathrm{AM}, 5=\mathrm{UC}+\mathrm{AM}+\mathrm{TCP}, 6=\mathrm{BAM}-4,7=\mathrm{BAM}-4+\mathrm{TCP}, 8=\mathrm{BAM}-12,9=\mathrm{BAM}-12+\mathrm{TCP}, 10=$ BAM-4+BAM-12, 11= BAM-4+BAM-12+ TCP,12= BAM-4 + AM, 13= BAM-4 + AM + TCP, 14= BAM-12 + $\mathrm{AM}, 15=\mathrm{BAM}-12+\mathrm{AM}+\mathrm{TCP}, 16=\mathrm{BAM}-4+\mathrm{BAM}-12+\mathrm{AM}$ and $17=\mathrm{BAM}-4+\mathrm{BAM}-12+\mathrm{AM}+\mathrm{TCP}$. Values are mean of 12 replicates. Bars indicate standard errors. BAM-4 - P. fluorescens, BAM-12- B. cepacia, AM- arbuscular mycorrhiza (G. etunicatum), SSP- single super phosphate, TCP- tricalcium phosphate.

\subsection{Dry weight of root}

Another parameter studied was the dry weight of roots. All treatments were statistically significant over the $\mathrm{UC}$ at $p<0.05$ significance level at both harvest dates (Table 1, Figure 5). The treatment BAM-4+BAM$12+\mathrm{AM}+\mathrm{TCP}$ was recorded as the best with regard to root dry weight too where 398.4 and $230.8 \%$ gain was observed at 45 and 110 DAS. The dry weights of roots with that treatment were also significantly higher compared to inoculations of single strains and commercial biofertilizer. Interestingly, the percent increase in almost all treatments was more in initial stage of the plant growth (45DAS) as compared to final harvest (110DAS).

\subsection{Crop yield}

Effect of co-inoculation of test organisms on the yield of wheat plants is depicted in Table 2 and Figure 6. All treated plants had significantly $(p<0.05)$ higher crop yield over the uninoculated control. Maximum increase in spike length $(90 \%)$, spike weight $(224 \%)$, grains per spike (220\%) and weight of 100 grains $(92.8 \%)$ was evident in the treatment having combination of 2 rhizobacterial strains along with AM and TCP at the 
time of harvesting. Single strain treatments (BAM4 and BAM-12) showed lesser or at par values in almost all the parameters as compared to SSP and biofertilizer. In general, rhizobacterial+AM performance was better than SSP and biofertilizer.

Table 1. Effect of co-inoculation of P solubilizing rhizobacteria and AM (Glomus etunicatum) on dry weight of shoot and root of wheat plants

\begin{tabular}{|c|c|c|c|c|c|}
\hline \multirow[t]{2}{*}{ S.No. } & \multirow[t]{2}{*}{ Treatments } & \multicolumn{2}{|c|}{ Shoot dry weight (mg plant ${ }^{-1}$ ) } & \multicolumn{2}{|c|}{ Root dry weight (mg plant ${ }^{-1}$ ) } \\
\hline & & 45 DAS & 110 DAS & 45 DAS & 110 DAS \\
\hline 1 & $\begin{array}{l}\text { Un-inoculated control } \\
\text { (UC) }\end{array}$ & $56.3 \pm 3.340$ & $77.75 \pm 2.28 q$ & $16 \pm 1.87 n$ & $33.25 \pm 6.46 q$ \\
\hline 2 & $\mathrm{UC}+\mathrm{SSP}$ & $\begin{array}{c}121.75 \pm 9.26 \mathrm{in} \\
(116.2) \\
\end{array}$ & $\begin{array}{c}328.5 \pm 4.15 p \\
(322.5)\end{array}$ & $\begin{array}{c}27.5 \pm 2.9 m \\
(71.8)\end{array}$ & $\begin{array}{c}49.5 \pm 5.89 p \\
(48.8)\end{array}$ \\
\hline 3 & UC+ Bio fertilizer & $\begin{array}{c}295.75 \pm 1.79 m \\
(425.3)\end{array}$ & $\begin{array}{c}409.75 \pm 6.420 \\
(426)\end{array}$ & $\begin{array}{c}44 \pm 4.72 \mathrm{dk} \\
(175)\end{array}$ & $\begin{array}{c}85.75 \pm 6.140 \\
(157.9)\end{array}$ \\
\hline 4 & $U C+A M$ & $\begin{array}{c}83 \pm 5.39 \mathrm{hl} \\
(47.4) \\
\end{array}$ & $\begin{array}{c}101.5 \pm 5.02 n \\
(30.5) \\
\end{array}$ & $\begin{array}{c}45.5 \pm 1.8 \mathrm{~m} \\
(184.3) \\
\end{array}$ & $\begin{array}{c}62 \pm 1.87 \mathrm{in} \\
(86.5) \\
\end{array}$ \\
\hline 5 & $\mathrm{UC}+\mathrm{AM}+\mathrm{TCP}$ & $\begin{array}{c}86.25 \pm 2.17 \mathrm{hk} \\
(53.2) \\
\end{array}$ & $\begin{array}{c}108.5 \pm 4.15 \mathrm{~m} \\
(39.5) \\
\end{array}$ & $\begin{array}{c}55.5 \pm 2.5 \text { gil } \\
(246.9)\end{array}$ & $\begin{array}{c}63.25 \pm 4.02 \mathrm{~m} \\
(90.2) \\
\end{array}$ \\
\hline 6 & BAM-4 & $\begin{array}{c}91.26 \pm 7.28 \mathrm{fj} \\
(62.1) \\
\end{array}$ & $\begin{array}{c}201.85 \pm 4.581 \\
(159.6) \\
\end{array}$ & $\begin{array}{c}40 \pm 5.59 \mathrm{dk} \\
(150)\end{array}$ & $\begin{array}{c}67.5 \pm 2.99 \mid \\
(103)\end{array}$ \\
\hline 7 & BAM-4 + TCP & $\begin{array}{c}120.5 \pm 4.52 \mathrm{in} \\
(113.1) \\
\end{array}$ & $\begin{array}{c}242.5 \pm 1.72 \mathrm{k} \\
(210.3) \\
\end{array}$ & $\begin{array}{c}52.25 \pm 5.31 \mathrm{ij} \\
(226.6)\end{array}$ & $\begin{array}{c}69.75 \pm 7.43 \mathrm{k} \\
(109.8)\end{array}$ \\
\hline 8 & BAM-12 & $\begin{array}{c}85.5 \pm 12.58 \mathrm{hkl} \\
(51.9)\end{array}$ & $\begin{array}{c}279.75 \pm 1.75 \mathrm{j} \\
(259.8) \\
\end{array}$ & $\begin{array}{c}52.5 \pm 1.89 \mathrm{cijl} \\
(228.1)\end{array}$ & $\begin{array}{c}76.5 \pm 3.96 h j \\
(130)\end{array}$ \\
\hline 9 & BAM-12 + TCP & $\begin{array}{c}94.08 \pm 1.74 \mathrm{fg} \\
(67.1)\end{array}$ & $\begin{array}{c}289 \pm 2.16 i \\
(271.7) \\
\end{array}$ & $\begin{array}{c}\text { 65t. 71bceh } \\
(306.2)\end{array}$ & $\begin{array}{c}61.25 \pm 1.52 \mathrm{in} \\
(84.2)\end{array}$ \\
\hline 10 & BAM-4+BAM-12 & $\begin{array}{c}92.25 \pm 5.23 \mathrm{fgj} \\
(63.9) \\
\end{array}$ & $\begin{array}{c}312.5 \pm 1.17 \mathrm{~h} \\
(301.9) \\
\end{array}$ & $\begin{array}{c}55.5 \pm 2.6 \mathrm{~g} \\
(246.9) \\
\end{array}$ & $\begin{array}{c}\text { 75.5 } \pm 1.18 \mathrm{hj} \\
(127.1) \\
\end{array}$ \\
\hline 11 & BAM-4+BAM-12+ TCP & $\begin{array}{c}210.25 \pm 5.67 e \\
(273.4) \\
\end{array}$ & $\begin{array}{c}392.75 \pm 4.79 g \\
(405.1)\end{array}$ & $\begin{array}{c}77.25 \pm 1.64 f \\
(382.8) \\
\end{array}$ & $\begin{array}{c}77.5 \pm 1.97 \mathrm{gj} \\
(133.8)\end{array}$ \\
\hline 12 & BAM-4 + AM & $\begin{array}{c}323.5 \pm 3.84 d \\
(474.6) \\
\end{array}$ & $\begin{array}{l}495 \pm 5 f \\
(536.7) \\
\end{array}$ & $\begin{array}{c}62 \pm 1 b \\
(287.5) \\
\end{array}$ & $\begin{array}{c}93.75 \pm 3.7 f \\
(182) \\
\end{array}$ \\
\hline 13 & $\mathrm{BAM}-4$ + AM + TCP & $\begin{array}{c}326.25 \pm 7.08 \mathrm{~d} \\
(479.5) \\
\end{array}$ & $\begin{array}{c}454.5 \pm 8.38 \mathrm{e} \\
(484.6) \\
\end{array}$ & $\begin{array}{c}65.75 \pm 2.59 \mathrm{eh} \\
(310.9) \\
\end{array}$ & $\begin{array}{c}106.25 \pm 3.9 \mathrm{e} \\
(219.5)\end{array}$ \\
\hline 14 & BAM-12 + AM & $\begin{array}{c}320 \pm 7.11 \mathrm{c} \\
(468.4) \\
\end{array}$ & $\begin{array}{c}484.25 \pm 8.87 d \\
(522.8) \\
\end{array}$ & $\begin{array}{c}38 \pm 2.55 \mathrm{dkl} \\
(137.5) \\
\end{array}$ & $\begin{array}{c}72.5 \pm 2.18 \mathrm{~d} \\
(118) \\
\end{array}$ \\
\hline 15 & $\mathrm{BAM}-12+\mathrm{AM}+\mathrm{TCP}$ & $\begin{array}{c}320.75 \pm 5.45 c \\
(469.7)\end{array}$ & $\begin{array}{c}520.25 \pm 2.86 c \\
(568.8)\end{array}$ & $\begin{array}{c}52.25 \pm 3.11 \mathrm{chij} \\
(226.6)\end{array}$ & $\begin{array}{c}76 \pm 1.58 \mathrm{cghj} \\
(128.5)\end{array}$ \\
\hline 16 & BAM-4+BAM-12+AM & $\begin{array}{c}355.75 \pm 6.3 b \\
(531.9) \\
\end{array}$ & $\begin{array}{c}509 \pm 7.28 \mathrm{~b} \\
(554.7) \\
\end{array}$ & $\begin{array}{c}62.75 \pm 3.56 b \\
(292.2) \\
\end{array}$ & $\begin{array}{c}98.25 \pm 1.48 b \\
(195.5) \\
\end{array}$ \\
\hline 17 & $\begin{array}{l}\text { BAM-4+BAM-12+ AM } \\
+ \text { TCP }\end{array}$ & $\begin{array}{c}387.75 \pm 4.82 a \\
(588.7)\end{array}$ & $\begin{array}{c}570 \pm 8.86 a \\
(633.1)\end{array}$ & $\begin{array}{c}79.75 \pm 3.49 a \\
(398.4)\end{array}$ & $\begin{array}{c}110 \pm 2.55 a \\
(230.8)\end{array}$ \\
\hline
\end{tabular}

Values are the mean of 12 replicates \pm SE. Mean values followed by the same letter within column are not significantly different $(p<0.05)$ by LSD. Values in the parentheses indicate percent increase over control. BAM-4 - P. fluorescens, BAM-12- B. cepacia, AM-Arbuscular mycorrhiza (G. etunicatum), UC- un inoculated control, TCP-tricalcium phosphate, SSP- single superphosphate, DAS- days after sowing. 


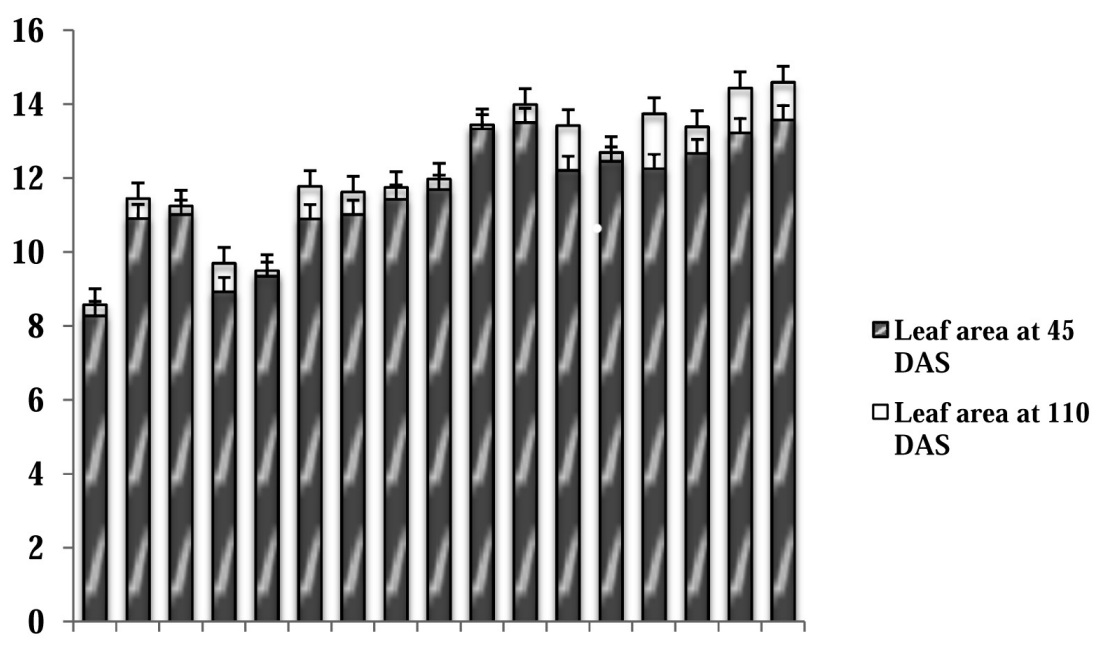

$\begin{array}{lllllllllllllllll}1 & 2 & 3 & 4 & 5 & 6 & 7 & 8 & 9 & 10 & 11 & 12 & 13 & 14 & 15 & 16 & 17\end{array}$

Figure 2. Leaf area 45 and 110 days after sowing (Treatments on $\mathrm{x}$-axis $1=\mathrm{Un}$-inoculated control (UC), $2=\mathrm{UC}+$ $\mathrm{SSP}, 3=\mathrm{UC}+$ Bio fertilizer, $4=\mathrm{UC}+\mathrm{AM}, 5=\mathrm{UC}+\mathrm{AM}+\mathrm{TCP}, 6=\mathrm{BAM}-4,7=\mathrm{BAM}-4+\mathrm{TCP}, 8=\mathrm{BAM}-12,9=$ BAM-12 + TCP, 10= BAM-4+BAM-12, 11= BAM-4+BAM-12+ TCP,12= BAM-4 + AM, 13= BAM-4 + AM + TCP, 14= BAM-12 + AM, 15= BAM-12 + AM + TCP, 16= BAM-4+BAM-12+ AM and 17= BAM-4+BAM-12+ AM +TCP. Values are mean of 12 replicates. Bars indicate standard error. BAM-4 - P. fluorescens, BAM-12- B. cepacia, AM- arbuscular mycorrhiza (G. etunicatum), SSP- single super phosphate, TCP- tricalcium phosphate.

\subsection{Percent root colonization by $A M$}

The results of percent root colonization by $\mathrm{AM}(G$. etunicatum) after 45 and 110 DAS in wheat plants inoculated with $\mathrm{AM}$ and rhizobacteria are given in Figure 3. Microscopic examination of stained roots showed a high percentage of mycorrhizal colonization in roots of all wheat plants treated with AM fungus along with PSB. In general, there was a significant increase in root colonization in the presence of single PSB or a combination of two PSB and AM fungus over the control. Root colonization by mycorrhizal fungus also increased significantly in plants inoculated with PSB and AM in presence of TCP; the best combination being BAM-4+BAM-12+ $\mathrm{AM}+\mathrm{TCP}$. This combination recorded the increase by
73 and $87.25 \%$ at 45 and 110 DAS, respectively. In general, the colonization increased with time as in all cases the colonization values were significantly more on $110^{\text {th }}$ day compared to $45^{\text {th }}$ day.

\subsection{Rhizosphere population of PSB}

It is evident from Figure 4 that in all the bacterial inoculated treatments, the population of PSB increased towards maturation of the crops. The number of PSB was significantly higher in the dual inoculation of two bacterial strains with $\mathrm{AM}$ in comparison to the single inoculation with AM. Higher number of PSB was recorded after harvesting of wheat, which was $4.25 \times 106$ cells $\mathrm{g}^{-1}$ at 110 DAS. 


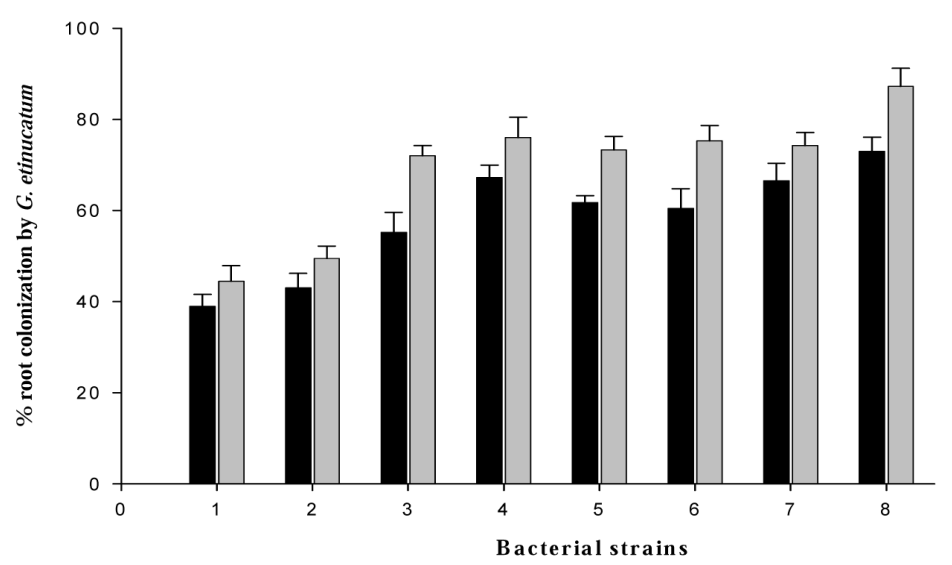

Figure 3. Percent root colonization by G. etunicatum $45(\square)$ and $110(\square)$ days after sowing (Treatments on x-axis $1=$ Soil+AM, 2= Soil+AM+TCP, 3= Soil+BAM-4+AM, 4= Soil+BAM-4+AM+TCP，5= Soil+BAM-12+AM, $6=$ Soil+BAM-12+AM+TCP, 7= Soil+BAM-4+BAM-12+AM, 8= Soil+BAM-4+BAM-12+AM+TCP. Values are mean of 12 replicates. Bars indicate standard error. BAM-4 - P. fluorescens, BAM-12- B. cepacia, AM- arbuscular mycorrhiza (G. etunicatum), TCP- tricalcium phosphate.

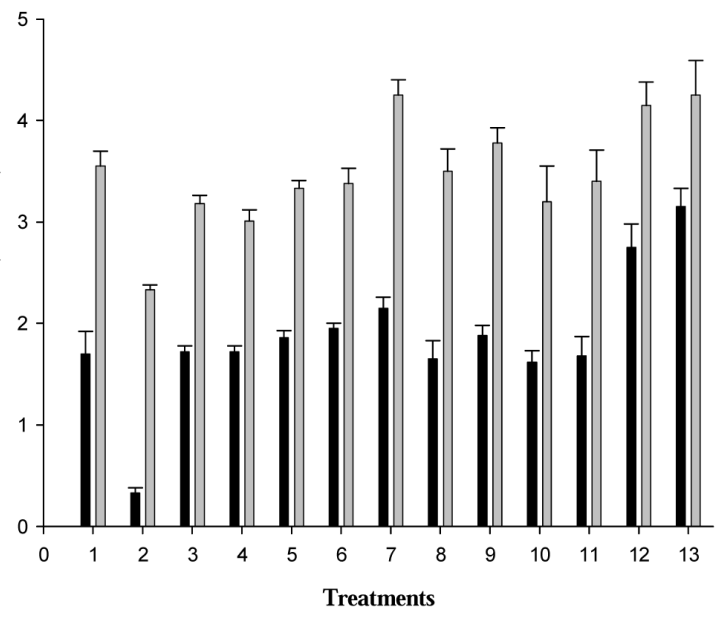

Figure 4. PSB counts $45(\boldsymbol{\square})$ and $110(\square)$ days after sowing (Treatments on $\mathrm{x}$-axis $1=$ Soil + Biogold biofertilizer, $2=$ Soil+BAM-4, 3= Soil+BAM-4+TCP, 4= Soil+BAM-12, 5= Soil+BAM-12+TCP, $6=$ Soil+BAM-4+BAM-12, 7= Soil+BAM4+BAM-12+TCP, 8= Soil+BAM-4+AM, 9= Soil+BAM-4+AM+TCP, 10= Soil+BAM-12+AM, 11= Soil+BAM-12+AM+TCP, $12=$ Soil+BAM-4+BAM-12+AM, 13= Soil+BAM-4+BAM-12+AM+TCP. Values are mean of 12 
Table 2. Effect of co-inoculation of P solubilizing rhizobacteria and AM (Glomus etunicatum) on spike length, spike weight, grains per spike and grain yield of wheat plants at the time of harvest

\begin{tabular}{|c|c|c|c|c|c|}
\hline S.No. & Treatments & Spike length $(\mathrm{cm})$ & Spike weight (mg) & Grains per spike & $\begin{array}{l}\text { Weight of } 100 \\
\text { grains }(\mathrm{g})\end{array}$ \\
\hline 1 & Un-inoculated control (UC) & $6.88 \pm 0.221$ & $201.5 \pm 4.56 n$ & $4 \pm 0.71 p$ & $2.23 \pm 0.13 d$ \\
\hline 2 & $U C+S S P$ & $\begin{array}{c}12.19 \pm 0.21 \mathrm{ck} \\
(77.2)\end{array}$ & $\begin{array}{c}393.7 \pm 4 \mathrm{ik} \\
(95.3)\end{array}$ & $\begin{array}{c}7.5 \pm 0.5 \mathrm{j} \\
(87.5)\end{array}$ & $\begin{array}{c}3.69 \pm 0.11 \mathrm{~b} \\
(65.5)\end{array}$ \\
\hline 3 & $U C+$ Bio fertilizer & $\begin{array}{c}12.5 \pm 0.94 \mathrm{bdj} \\
(81.6)\end{array}$ & $\begin{array}{c}466 \pm 1.5 \mathrm{~m} \\
(131.3)\end{array}$ & $\begin{array}{c}10.7 \pm 0.71 \mathrm{cdno} \\
(167.5)\end{array}$ & $\begin{array}{c}3.72 \pm 0.38 \mathrm{~b} \\
(66.8)\end{array}$ \\
\hline 4 & $U C+A M$ & $\begin{array}{c}8.25 \pm 0.83 i \\
(19.9)\end{array}$ & $\begin{array}{c}330 \pm 0.081 \\
(63.8)\end{array}$ & $\begin{array}{c}6.25 \pm 0.83 \mathrm{~m} \\
(56.3)\end{array}$ & $\begin{array}{c}2.68 \pm 0.29 c \\
(20.2)\end{array}$ \\
\hline 5 & $U C+A M+T C P$ & $\begin{array}{c}8.7 \pm 0.41 \mathrm{~h} \\
(26.4)\end{array}$ & $\begin{array}{c}398 \pm 4.5 \mathrm{k} \\
(97.5)\end{array}$ & $\begin{array}{c}6.75 \pm 0.83 \text { gikl } \\
(68.8)\end{array}$ & $\begin{array}{c}2.85 \pm 0.27 \mathrm{c} \\
(15.7)\end{array}$ \\
\hline 6 & BAM-4 & $\begin{array}{c}9.5 \pm 0.11 \mathrm{~g} \\
(38.1)\end{array}$ & $\begin{array}{l}362 \pm 4 j \\
(79.7)\end{array}$ & $\begin{array}{c}7 \pm 0.18 \text { ghik } \mid \\
(75)\end{array}$ & $\begin{array}{c}3.6 \pm 0.07 b \\
(54.5)\end{array}$ \\
\hline 7 & BAM- $4+$ TCP & $\begin{array}{c}9.77 \pm 0.12 \mathrm{fg} \\
(42)\end{array}$ & $\begin{array}{c}390 \pm 2.7 i \\
(93.5)\end{array}$ & $\begin{array}{c}7.34 \pm 0.11 \text { hjo } \\
(83.5)\end{array}$ & $\begin{array}{c}3.9 \pm 0.07 \mathrm{~b} \\
(67.4)\end{array}$ \\
\hline 8 & BAM-12 & $\begin{array}{c}9.54 \pm 0.07 \mathrm{~g} \\
(38.7)\end{array}$ & $\begin{array}{c}375 \pm 5 h \\
(86.1)\end{array}$ & $\begin{array}{c}6.9 \pm 0.1 \text { hikl } \\
(72.5)\end{array}$ & $\begin{array}{c}3.68 \pm 0.08 \mathrm{~b} \\
(24.9)\end{array}$ \\
\hline 9 & BAM-12 + TCP & $\begin{array}{c}9.80 \pm 0.07 \text { ef } \\
(42.4)\end{array}$ & $\begin{array}{c}381.93 \pm 1.5 \mathrm{~h} \\
(89.5)\end{array}$ & $\begin{array}{c}7.14 \pm 0.15 \mathrm{ghijkl} \\
(78.5)\end{array}$ & $\begin{array}{c}3.8 \pm 0.07 \mathrm{~b} \\
(63.1)\end{array}$ \\
\hline 10 & BAM-4+BAM-12 & $\begin{array}{c}10.09 \pm 0.0 \text { ef } \\
(46.6)\end{array}$ & $\begin{array}{c}489.5 \pm 4.92 \mathrm{~g} \\
(142.9)\end{array}$ & $\begin{array}{c}6.9 \pm 0.07 \mathrm{gik} \\
(72.5)\end{array}$ & $\begin{array}{c}3.8 \pm 0.07 \mathrm{~b} \\
(63.1)\end{array}$ \\
\hline 11 & BAM-4+BAM-12+ TCP & $\begin{array}{c}12.5 \pm 0.94 \mathrm{bdj} \\
(81.6)\end{array}$ & $\begin{array}{c}520 \pm 4.1 f \\
(158.7)\end{array}$ & $\begin{array}{c}9.43 \pm 0.15 f \\
(135.8)\end{array}$ & $\begin{array}{c}3.63 \pm 0.27 \mathrm{~b} \\
(62.8)\end{array}$ \\
\hline 12 & BAM-4 + AM & $\begin{array}{c}12.08 \pm 0.33 \mathrm{ck} \\
(75.6)\end{array}$ & $\begin{array}{c}541.75 \pm 7.67 d \\
(168.9)\end{array}$ & $\begin{array}{c}9.4 \pm 0.31 \mathrm{f} \\
(135)\end{array}$ & $\begin{array}{c}4.2 \pm 0.15 a \\
(80.3)\end{array}$ \\
\hline 13 & $\mathrm{BAM}-4+\mathrm{AM}+\mathrm{TCP}$ & $\begin{array}{c}12.1 \pm 0.38 \mathrm{ck} \\
(75.9)\end{array}$ & $\begin{array}{c}581.75 \pm 5.40 \mathrm{e} \\
(188.7)\end{array}$ & $\begin{array}{c}10.23 \pm 0.29 \mathrm{e} \\
(155.8)\end{array}$ & $\begin{array}{c}3.76 \pm 0.04 \mathrm{~b} \\
(68.8)\end{array}$ \\
\hline 14 & BAM-12 + AM & $\begin{array}{c}12.7 \pm 0.19 \mathrm{bdj} \\
(84.6)\end{array}$ & $\begin{array}{c}537.5 \pm 7.2 \mathrm{~d} \\
(166.7)\end{array}$ & $\begin{array}{c}10.58 \pm 0.38 \mathrm{~d} \\
(164.5)\end{array}$ & $\begin{array}{c}3.73 \pm 0.19 \mathrm{~b} \\
(67.3)\end{array}$ \\
\hline 15 & $B A M-12+A M+T C P$ & $\begin{array}{c}12.88 \pm 0.29 a \\
(87.2)\end{array}$ & $\begin{array}{c}589.5 \pm 4.82 \mathrm{c} \\
(192.6)\end{array}$ & $\begin{array}{c}11.0 \pm 0.28 \mathrm{cn} \\
(175)\end{array}$ & $\begin{array}{c}3.75 \pm 0.18 \mathrm{~b} \\
(68.2)\end{array}$ \\
\hline 16 & BAM-4+BAM-12+ AM & $\begin{array}{c}13 \pm 0.35 a \\
(89)\end{array}$ & $\begin{array}{c}633.75 \pm 2.86 \mathrm{~b} \\
(214.5)\end{array}$ & $\begin{array}{c}11.63 \pm 0.36 \mathrm{~b} \\
(190.8)\end{array}$ & $\begin{array}{c}4.1 \pm 0.16 \mathrm{a} \\
(83.9)\end{array}$ \\
\hline 17 & BAM-4+BAM-12+AM +TCP & $\begin{array}{c}13.08 \pm 0.36 a \\
(90)\end{array}$ & $\begin{array}{c}653 \pm 4.3 a \\
(224)\end{array}$ & $\begin{array}{c}12.8 \pm 0.25 a \\
(220)\end{array}$ & $\begin{array}{c}4.3 \pm 0.19 \mathrm{a} \\
(92.8)\end{array}$ \\
\hline
\end{tabular}

Values are the mean of 12 replicates \pm SE. Mean values followed by the same letter within column are not significantly different $(p<0.05)$ by LSD. Values in the parentheses indicate percent increase over control. BAM-4 - P. fluorescens, BAM-12- B. cepacia, AM- Arbuscular mycorrhiza (G. etunicatum), UC- uninoculated control, TCP- tricalcium phosphate, SSP- single superphosphate, DAS- days after sowing.

\subsection{Total $P$ and $N$ content in shoot}

$\mathrm{P}$ and $\mathrm{N}$ content in shoots of all treatments were significantly $(p<0.05)$ higher than in the control (UC) (Table 3). Inoculation of rhizobacteria with G. etunicatum overall increased total $\mathrm{P}$ uptake but a significant increase was observed when both rhizobacteria and $G$. etunicatum were inoculated together. However, the $\mathrm{P}$ concentration in shoots differed among the microbial treatments. The maximum percent increase in $\mathrm{P}$ and $\mathrm{N}$ content over the control was $171 \%$ and $145.8 \%$ in BAM-12+BAM- 4 amended with $\mathrm{AM}+\mathrm{TCP}$ at 45 and $110 \mathrm{DAS}$, respectively, whereas the least $\mathrm{P}$ increase was recorded in $\mathrm{UC}+\mathrm{AM}$ $(21.4 \%)$ and least $\mathrm{N}$ increase in UC+SSP (2\%).

\section{Discussion}

The synergistic effect of G. etunicatum, an AM fungus and 2 rhizobacteria $P$. fluorescens BAM-4 and $B$. cepacia BAM-12, which are able to solubilize insoluble phosphorus was studied in wheat plants grown in sterile soil to determine their effect on plant growth and yield. 
Table 3. Effect of co-inoculation of P solubilizing rhizobacteria and AM (Glomus etunicatum) on percent $\mathrm{P}$ and $\mathrm{N}$ content in wheat plants

\begin{tabular}{|c|c|c|c|}
\hline S.No. & Treatments & $\begin{array}{l}\% \mathrm{P} \text { content in } \\
0.1 \mathrm{~g} \text { sample }\end{array}$ & $\begin{array}{c}\% \mathrm{~N} \text { content in } \\
0.1 \mathrm{~g} \text { sample }\end{array}$ \\
\hline 1 & Un-inoculated control (UC) & $0.14 \pm 0.01 n$ & $0.48 \pm 0.021 \mathrm{mn}$ \\
\hline 2 & $U C+S S P$ & $\begin{array}{c}0.33 \pm 0.01 \mathrm{hm} \\
(135.7)\end{array}$ & $\begin{array}{c}0.49 \pm 0.06 \mathrm{Imn} \\
(2.0)\end{array}$ \\
\hline 3 & UC+ Bio fertilizer & $\begin{array}{c}0.26 \pm 0.03 \text { beij } \\
(85.7)\end{array}$ & $\begin{array}{c}0.51 \pm 0.05 \mathrm{jlmn} \\
(6.3)\end{array}$ \\
\hline 4 & $U C+A M$ & $\begin{array}{c}0.17 \pm 0.03 \mathrm{k} \\
(21.4)\end{array}$ & $\begin{array}{c}0.59 \pm 0.08 \mathrm{jk} \\
(22.9)\end{array}$ \\
\hline 5 & $U C+A M+T C P$ & $\begin{array}{c}0.20 \pm 0.01 \mathrm{gil} \\
(42.9)\end{array}$ & $\begin{array}{c}0.55 \pm 0.08 \mathrm{jklm} \\
(14.6)\end{array}$ \\
\hline 6 & BAM-4 & $\begin{array}{c}0.19 \pm 0.01 \mathrm{k} \\
(35.7)\end{array}$ & $\begin{array}{c}0.56 \pm 0.01 \mathrm{jkm} \\
(16.7)\end{array}$ \\
\hline 7 & BAM-4 + TCP & $\begin{array}{c}0.26 \pm 0.01 \text { bej } \\
(85.7)\end{array}$ & $\begin{array}{c}0.54 \pm 0.01 \mathrm{jl} \\
(12.5)\end{array}$ \\
\hline 8 & BAM-12 & $\begin{array}{c}0.24 \pm 0.02 \text { bgil } \\
(71.4)\end{array}$ & $\begin{array}{c}0.73 \pm 0.01 \mathrm{cdh} \\
(52.1)\end{array}$ \\
\hline 9 & BAM-12 + TCP & $\begin{array}{c}0.32 \pm 0.01 \mathrm{~h} \mathrm{~m} \\
(128.5)\end{array}$ & $\begin{array}{c}0.93 \pm 0.01 \mathrm{bi} \\
(93.8)\end{array}$ \\
\hline 10 & BAM-4+BAM-12 & $\begin{array}{c}0.23 \pm 0.01 \mathrm{gil} \\
(64.3)\end{array}$ & $\begin{array}{c}0.77 \pm 0.01 d \\
(60.4)\end{array}$ \\
\hline 11 & BAM-4+BAM-12+ TCP & $\begin{array}{c}0.37 \pm 0.01 \mathrm{adf} \\
(164.3)\end{array}$ & $\begin{array}{c}0.87 \pm 0.33 \mathrm{fg} \\
(81.25)\end{array}$ \\
\hline 12 & BAM-4 + AM & $\begin{array}{c}0.26 \pm 0.01 \text { bej } \\
(85.7)\end{array}$ & $\begin{array}{c}0.84 \pm 0.02 \mathrm{efg} \\
(75)\end{array}$ \\
\hline 13 & BAM-4 + AM + TCP & $\begin{array}{c}0.36 \pm 0.03 a c d f \\
(157.1) \\
\end{array}$ & $\begin{array}{c}0.82 \pm 0.21 \mathrm{ef} \\
(70.8)\end{array}$ \\
\hline 14 & BAM-12 + AM & $\begin{array}{c}0.24 \pm 0.02 \mathrm{bgij} \\
(71.4)\end{array}$ & $\begin{array}{c}0.74 \pm 0.11 \mathrm{cdh} \\
(54.2)\end{array}$ \\
\hline 15 & BAM-12 + AM + TCP & $\begin{array}{c}0.35 \pm 0.03 \mathrm{cdm} \\
(150)\end{array}$ & $\begin{array}{c}0.70 \pm 0.01 \mathrm{~cd} \\
(54.2)\end{array}$ \\
\hline 16 & BAM-4+BAM-12+ AM & $\begin{array}{c}0.26 \pm 0.02 \text { beij } \\
(85.7)\end{array}$ & $\begin{array}{c}0.96 \pm 0.22 b \\
(100)\end{array}$ \\
\hline 17 & BAM-4+BAM-12+AM +TCP & $\begin{array}{c}0.38 \pm 0.03 a d f \\
(171.4)\end{array}$ & $\begin{array}{c}1.18 \pm 0.09 a i \\
(145.8)\end{array}$ \\
\hline
\end{tabular}

Values are the mean of 12 replicates \pm SE. Mean values followed by the same letter within column are not significantly different $(p<0.05)$ by LSD. Values in the parentheses indicate percent increase over control. BAM-4 - P. fluorescens, BAM-12 - B. cepacia, AM- Arbuscular mycorrhiza (G. etunicatum), UC- uninoculated control, TCP- tri calcium phosphate, SSP- single superphosphate, DAS- days after sowing. 
The higher germination rate observed in inoculated treatments during this experiment may be due to plant growth promoting activities of the 2 bacterial strains. Although at this stage the germinating seeds receive most of the nutrients from seed reserves, plant growth hormones such as auxin or gibberellic acid produced by rhizobacteria may act as stimulants (Minaxi et al., 2012).

The leaf area was studied and it was found that when chemical fertilizer, SSP was compared with other treatments, all except single inoculation of BAM-4 showed significantly higher results. Increased leaf area may directly influence the photosynthesis efficiency of the plant, thereby, contributing towards the superior performance of the plants.

All rhizobacterial+AM treatments showed a significant increase in shoot dry weight compared to SSP treated plants 45 and 110 DAS except for the single rhizobacterial treatments. This significant increase can be attributed to the positive interaction between rhizobacterial inoculants and AM fungus. Recently, Khan et al. (2008) reported that inoculation of Medicago sativa with Gigaspora rosea, Glomus intraradices+Gigaspora rosea and Glomus etunicatum + Glomus intraradices showed significantly increased shoot and root dry weight. Glomus intraradices inoculation caused a significant growth depression in grapevine shoots initially, but only five months after the plants establishment in the high lime content replant soil, mycorrhizal plants outgrew the non-inoculated control plants with significantly higher biomass (Nogales et al., 2009).

Overall the root dry weights were higher in most bacterial treatments compared to the fertilizer controls. Khan et al. (2008) also reported increased root dry weight in Medicago sativa after dual inoculation with Glomus intraradices+Gigaspora rosea and Glomus etunicatum + Glomus intraradices.

In general, the combination of rhizobacteria and AM resulted in higher wheat yield compared to the SSP and biofertilizer controls. These findings have also been reported by many researchers while investigating the inoculation effect of different species of phosphate solubilizing bacteria and AM fungi on a variety of crop plants (Zaidi et al., 2003; Zaidi and Khan, 2005). Both rhizobacterial strains used in this study have earlier been shown to produce chitinase and BAM4 also produced siderophores. They have also been considered as potential biocontrol agents in mung beans against Macrophomina phaseolina (Minaxi and Saxena, 2010). Therefore, BAM-4 and BAM-12 strains could have indirectly supported the overall growth of the plants along with direct effect of AM fungus on nutrient uptake. The results in this study showed significant differences when strains were used in dual combination treatment compared to single inoculations of AM fungus or PSB strains, BAM-4 and BAM-12.

Singh and Singh (1993) attributed the enhancement of root colonization by AM fungi in the presence of Mussoorie Rock Phosphate and the microbial inoculants to changes in root morphology and physiology. Profuse proliferation and colonization of mycorrhiza in roots could be due to the synergistic effect with rhizobacteria. Both the strains produced hormones (Minaxi, 2009) which apparently stimulated the AM infection.

Higher abundances of PSB were recorded after

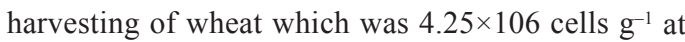
110 DAS. It shows that the introduced bacteria could survive, proliferate and colonize the rhizosphere of plants. The results are in close conformity with those reported by Reid (1990) and Barea et al. (2005). The PSB abundances were either higher or comparable to the bioinoculant treated wheat plant rhizosphere, when compared with commercial biofertilizer which shows their better survival capability. George et al. (1995) and Chen et al. (2005) reported that colonization of plant roots by arbuscular mycorrhizal fungi greatly increased the plant uptake of $\mathrm{P}$ and $\mathrm{N}$. 
The greater $\mathrm{P}$ uptake in plants inoculated with PSB and the AM fungus in the presence of TCP can be attributed to the transport of $\mathrm{P}$ by the $\mathrm{AM}$ fungus that was solubilized by PSB. The enhanced uptake could also be due to an increase in the number of uptake sites per unit area of roots and a greater ability of these roots to exploit the soil for nutrients. AM hyphae are also known to transport inorganic $\mathrm{N}$ to the roots (Johansen et al., 1996).

The co-inoculation of rhizobacteria and AM along with TCP enhanced the overall growth of wheat plants, which was significantly higher than under chemical fertilizer (SSP) and biofertilizer (Biogold) treatments. In general, inoculation with PSB and AM fungus together resulted in higher growth and yield of wheat plants than when these organisms were used alone. These results are in concurrence with Piccini and Azcon (1987) who reported significant increase in grain yields in alfalfa plants.
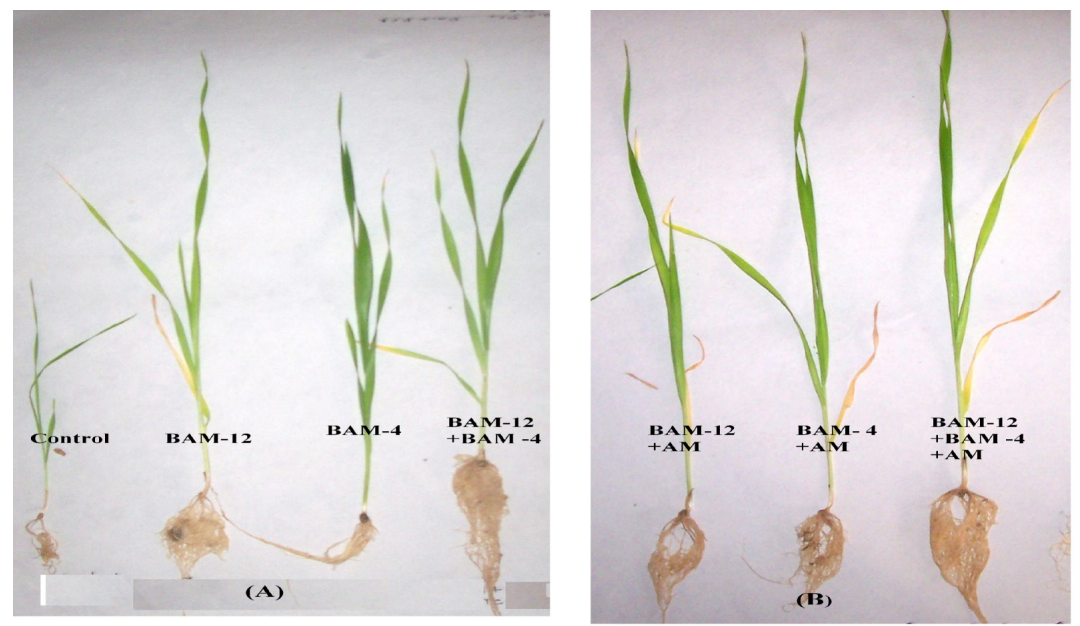

Figure 5. Wheat plants amended with TCP and rhizobacterial strains (A) without G. etunicatum (B) rhizobacterial strains with G. etunicatum at 45 DAS 


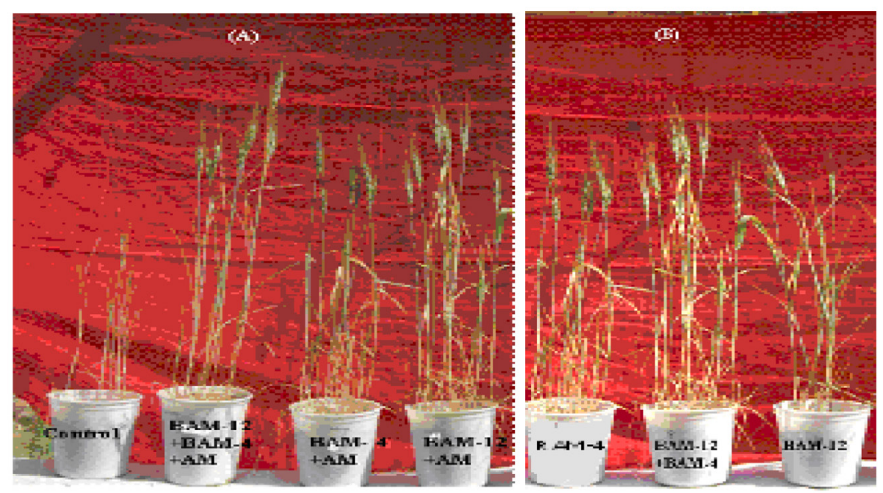

Figure 6. Wheat plants inoculated with rhizobacterial strains along with TCP (A) with G. etunicatum (B) without G. etunicatum at harvest

\section{Conclusions}

In conclusion, this study revealed that the mixed inoculation of plant growth promoting rhizobacteria, especially the PSB, P. fluorescens BAM-4 and B. cepacia BAM-12 and AM fungus, G. etunicatum improved the plant growth and nutrient uptake and showed a significant increase in grain yield of wheat plants in comparison to single inoculations of any of these strains. Thus, in nutrient deficient semi arid soils the inoculation of plants with a combination of PSB and mycorrhizal fungi may help the plants to obtain P from native insoluble P sources and would be beneficial for a sustainable nutrient management and reduction on chemical fertilizers especially in developing countries like India. It can also play a role in making organic farming sustainable and cost effective. However, their application needs to be further evaluated under different agro climatic conditions in the field.

\section{Acknowledgement}

The AM inoculum provided by Dr. D. J. Bagyaraj, University of Agricultural Sciences, Bangalore, India is greatly acknowledged.

\section{References}

Allen, S.E. 1989. Chemical analysis of ecological materials. In: S.E. Steward (ed). Blackman Scientific Publications, Oxford, U.K.

AOAC, 1965. Official methods of analysis. 10th ed. Association of official agricultural chemists, Washigton DC.

Anamika, Saxena, J., Sharma, V. 2007. Isolation of tricalcium phosphate solubilizing strains from semi-arid agricultural fields of Rajasthan, India. J Pure Appl. Microbiol. 1, 269-280. 
Barea, J.M., Toro, M., Orozco, M.O., Campos, E, Azcón, R. 2002. The application of isotopic $32 \mathrm{P}$ and $15 \mathrm{~N}$-dilution techniques to evaluate the interactive effect of phosphate-solubilizing rhizobacteria,mycorrhizal fungi and Rhizobium to improve the agronomic efficiency of rock phosphate for legume crops. Nutr. Cycl. Agroeco. 63, 35-42.

Barea, J.M., Pozo, M.J., Azcon, R., Azcon-Aguilar, C. 2005. Microbial cooperation In the rhizosphere. J Exp. Bot. 56, 1761-1778.

Chen, X., Tang, J.J., Zhi, G.Y., Hu, S.J. 2005. Arbuscular mycorrhizal colonization and phosphorus acquisition of plants and effects of coexisting plant species. App. Soil Eco. 28, 259-269.

Clark, R.B., Zeto, S.K. 2000. Mineral acquisition by arbuscular mycorrhizal plants. J P1. Nutr. 23, 867-902.

Evans, D.G., Miller, M.H. 1990. The role of external mycelial network and the effect of soil disturbance upon vessicular arbuscular mycorrhizal colonization of maize. New Phyto. 114, 65-71.

George, E., Marchner, H., Jakobsen, I. 1995. Role of arbuscular mycorrhizal fungi in uptake of phosphorus and nitrogen from soil. Critical Rev. Biotech. 15, 257270 .

Göhre, V., Paszkowski, U. 2006. Contribution of the arbuscular mycorrhizal symbiosis to heavy metal phytoremediation. Planta. 223, 1115-1122.

Igual, J.M., Valverde, A., Cervantes, E., Velazquez, E. 2001. Phosphate solubilizing bacteria as inoculants for agriculture: use of updated molecular techniques in their study. Agronomy 21, 561-568.

Illmer, P., Barbato, A., Schinner, F. 1995. Solubilization of hardly soluble $\mathrm{AlPO}_{4}$ with $\mathrm{P}$ - solubilizing microorganisms. Soil Biol. Biochem. 27, 265-270.

Jackson, M.L. 1967. Soil chemical analysis, Prentice Hall of India Private Limited, New Delhi, pp 205.
Jeffries, S., Gianinazzi, S., Perotto, S., Turnau, K., Barea, J.M. 2003. The contribution of arbuscular mycorrhizal fungi in sustainable maintenance of plant health and soil fertility. Biol. Fert. Soils 37, 1-16.

Johansen, A., Finlay, R.D., Olsson, P.A. 1996. Nitrogen metabolism of external hyphae of the arbuscular mycorrhizal fungus Glomus intraradices. New Phytol. 133, 705-712.

Jones, N.P., Sreenivasa, M.N. 1993. Effect of inoculation of VA mycorrhiza and/or phosphate solubilizing bacteria on rhizosphere microflora of sunflower II. J. Ecotoxicol. Environ. Monit. 3, 55-58.

Khan, I.A., Ayub, N., Mirza, S.N., Nizami, S.M., Azam, M. 2008. Synergistic effect of dual inoculation (Vasicular arbuscular mycorrhizae) on the growth and nutrients uptake of Medicago sativa. Pak. J. Bot. 40, 939-945.

Mamatha, G., Bagyaraj, D.J., Jaganath, S. 2002. Inoculation of Inoculation of field-established mulberry and papaya with arbuscular mycorrhizal fungi and a mycorrhiza helper bacterium. Mycorrhiza $12,313-316$.

Minaxi, Nain L., Yadav R.C., Saxena J. 2012. Characterization of multifaceted Bacillus sp RM-2 for its use as plant growth promoting bioinoculant for crops grown in semi arid deserts. Appl. Soil Eco. 59, 124-135.

Minaxi, Saxena, J. 2010. Disease suppression and crop improvement in moong beans (Vigna radiata) through Pseudomonas and Burkholderia strains isolated from semi arid region of Rajasthan, Bio.Cont. 55 (6), 799810 .

Nogales, A., Luque, J., Victoria, E., Camprubí, A., Garcia-Figueres, F., Calvet, C. 2009. Differential Growth of mycorrhizal field-inoculated grapevine rootstocks in two replant soils Am. J. Enol. Vitic. 60, 484-489. 
Olsen, S.R., Sommers, L.E. 1982. Phosphorus. In: A.L. Page, R.H. Miller, D.R. Keeny (eds). Methods of soil analysis: Part 2. Chemical and microbiological properties Agron. Mongr. 9. 2nd ed. ASA and SSSA, Madison, WI. pp. 403-430.

Olsen, S.R., Cole, C.V., Watanabe, F.S., Dean, L.A. 1954. Estimation of available $P$ in soil by extraction with sodium bicarbonate. US Department of Agriculture Circular, pp: 93.

Phillips, J.M., Hayman, D.S. 1970. Improvement procedure for cleaning and staining parasitic and vesicular arbuscular mycorrhizal fungi for rapid assessment of infections. Trans. Brit. Mycol. Soc. 55, 158-161.

Piccini, D., Azcon, R. 1987. Effect of phosphate solubilizing bacteria and vesicular-arbuscular mycorrhizal fungi on the utilization of Bayovar rockphosphate by alfalfa plants using a sand vermiculite medium. Plant Soil 50, 45-50.

Raj, J., Bagyaraj, D.J., Manjunath, A. 1981. Influence of soil inoculation with vesicular arbuscular mycorrhiza and a phosphate dissolving bacterium on plant growth and $\mathrm{P}^{32}$-uptake. Soil Biol. Biochem. 13, 105-108.

Raja, A.K., Shah, K.H., Aslam, M., Memon, M.Y. 2002. Response of phosphobacterial and mycorrhizal inoculation in wheat. Asian J. Plant Sc. 1, 322-323.

Reid, C.P.P. 1990. Mycorrhizas. In The rhizosphere J.M. Lynch (ed). Wiley Chichester, UK pp 281-315.

Rodriguez, H., Fraga, R. 1999. Phosphate solubilizing bacteria and their role in plant growth promotion. Biotechnol. Advan. 17, 319-339.
Sanchez-Blanco, M.J., Ferrandez, T., Morales, M.A., Morte, A., Alarcon, J.J. 2004. Variations in water status, gas exchange, and growth in Rosmarinus officinalis plants infected with Glomus deserticola under drought conditions. J. Plant Physiol. 161, 675-682.

Singh, S., Kapoor, K.K. 1998. effects of inoculation of phosphate solubiliizing microorganisms and an arbuscular mycorrhizal fungus on growth of mung beans grown under natural soil conditions. Mycorrhiza 7, 249-253.

Singh, H.P., Singh, T.A. 1993. The interaction of rockphosphate Bradyrhizobium vesicular-arbuscular mycorrhizae and phosphate- solubilizing microbe on soybean grown in a sub Himalayan mollisol. Mycorrhiza 4, 37-43.

Souchie, E.L., Orivaldo, J., Saggin-Junior, O.J., Silva, E.M.R., Campello, E.F.C., Azcon, R., Barea, J.M. 2006. Communities of $\mathrm{P}$ solubilizing bacteria, fungi and arbuscular mycorrhizal fungi in grass pasture and secondary forest of Paraty RJ-Brazil. Anais da Academia Brasileira de Ciências 78, 183-193.

Wu, Q.S., Xia, R.X. 2006. Arbuscular mycorrhizal fungi influence growth, osmotic adjustment and photosynthesis of citrus under well-watered and water stress conditions. J. Plant Physiol. 163, 417-425.

Zaidi, A., Khan, M.S. 2005. Interactive effect of rhizospheric microorganisms on growth yield and nutrient uptake of wheat. J. Plant Nutr. 28, 2079-2092.

Zaidi, A., Khan, M.S., Amil, M. 2003. Interactive effect of rhizotrophic microorganisms on yield and nutrient uptake of chickpea (Cicer arietinum L.). Eur. J. Agron. 19, 15-21. 